\title{
ERRATUM
}

S. G. Cox $\cdot$ A. Numanoglu $\cdot$ A. J. W. Millar $\cdot$ H. Rode

\section{Colonic atresia: spectrum of presentation and pitfalls in management: a review of 14 cases}

Published online: 18 November 2005

(C) Springer-Verlag 2005

Paediatr Surg Int (2005). DOI: 10.1007/s00383-005-

1488-4

This article was mistakenly published as a Case Report.

In fact, it is an Original Article.

The online version of the original article can be found at http://dx.doi.org/10.1007/s00383-005-1488-4

S. G. Cox · A. Numanoglu · A. J. W. Millar · H. Rode $(\bowtie)$ Department of Paediatric Surgery, Red Cross War Memorial Children's Hospital \& School of Child and Adolescent Health, University of Cape Town, Klipfontein Road, Rondebosch 7700, South Africa

E-mail: hrode@ich.uct.ac.za

Tel.: + 27-21-658-5339

Fax: + 27-21-685-6332 